\title{
"Exploring leadership factors creating employee engagement or disengagement across job grade categories at a public higher education institution in South Africa"
}

\begin{tabular}{|c|c|}
\hline AUTHORS & $\begin{array}{l}\text { Anrusha Bhana (D https://orcid.org/0000-0001-5577-6728 } \\
\text { R https://publons.com/researcher/ABE-6081-2021/ } \\
\text { Sachin Suknunan (D https://orcid.org/0000-0002-7296-8059 }\end{array}$ \\
\hline ARTICLE INFO & $\begin{array}{l}\text { Anrusha Bhana and Sachin Suknunan (2021). Exploring leadership factors } \\
\text { creating employee engagement or disengagement across job grade categories at } \\
\text { a public higher education institution in South Africa. Problems and Perspectives } \\
\text { in Management, 19(1), 317-327. doi:10.21511/ppm.19(1).2021.27 }\end{array}$ \\
\hline DOI & http://dx.doi.org/10.21511/ppm.19(1).2021.27 \\
\hline RELEASED ON & Thursday, 18 March 2021 \\
\hline RECEIVED ON & Sunday, 05 April 2020 \\
\hline ACCEPTED ON & Tuesday, 25 August 2020 \\
\hline LICENSE & $\begin{array}{l}(c)) E Y \\
\text { This work is licensed under a Creative Commons Attribution } 4.0 \text { International } \\
\text { License }\end{array}$ \\
\hline JOURNAL & "Problems and Perspectives in Management" \\
\hline ISSN PRINT & $1727-7051$ \\
\hline ISSN ONLINE & $1810-5467$ \\
\hline PUBLISHER & LLC "Consulting Publishing Company "Business Perspectives" \\
\hline FOUNDER & LLC "Consulting Publishing Company "Business Perspectives" \\
\hline
\end{tabular}

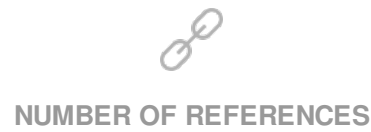

46
NUMBER OF FIGURES

0
NUMBER OF TABLES

3

(C) The author(s) 2022. This publication is an open access article. 


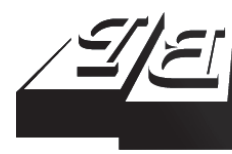

\section{BUSINESS PERSPECTIVES}

(2)

LLC "CPC "Business Perspectives" Hryhorii Skovoroda lane, 10, Sumy, 40022, Ukraine www.businessperspectives.org

Received on: $5^{\text {th }}$ of April, 2020 Accepted on: $25^{\text {th }}$ of August, 2020 Published on: $18^{\text {th }}$ of March, 2021

(c) Anrusha Bhana,

Sachin Suknunan, 2021

Anrusha Bhana, Ph.D., Acting Head, Faculty of Accounting and Informatics, Department of Financial Accounting Durban University of Technology, Durban, South Africa.

Sachin Suknunan, Doctor of Business Administration, Student Services Division, University of KwaZulu-Natal, Durban, South Africa. (Corresponding author)
EXPLORING LEADERSHIP FACTORS CREATING EMPLOYEE ENGAGEMENT OR DISENGAGEMENT ACROSS JOB GRADE CATEGORIES AT A PUBLIC HIGHER EDUCATION INSTITUTION IN SOUTH AFRICA

\begin{abstract}
Ongoing difficulties in promoting employee commitment confront the domain of higher education, hence, the importance of staff to help achieve institutional goals grows. For this to happen, employee engagement is key. This paper examined the issues of engagement or disengagement amongst employees, including job grades and the factors influencing this, at Durban University of Technology, South Africa. It adopted a quantitative and qualitative method of inquiry. The quantitative data collection targeted 420 employees utilizing questionnaires and obtained a response rate of 312 (74\%). The qualitative aspect involved interviewing 12 out of 18 leadership personnel, giving a response rate of $67 \%$. Also, descriptive and inferential analysis was used. Internal employee engagement demonstrated a significant difference across job level categories, $\mathrm{F}(4,307)=4.012, \mathrm{p}=0.003$. There is also a significant difference in agreement mean score, which is lower for lecturer grade level $(\mathrm{M}=2.5257, \mathrm{SD}=1.08359)$ than middle manager grade level $(\mathrm{M}=3.2909, \mathrm{SD}=0.82396)$, showing that lecturer grade level is more engaged as compared to the middle manager level reflecting that the this level is not as engaged as it should be. Obtained qualitative results showed that there was minimal employee engagement. Overall, there was more employee disengagement than engagement at the institution, leading to employee stress, increased employee turnover and minimal employee productivity. This can, in turn, affect institutional productivity. However, leadership viewed employee engagement as important and something to be further developed.
\end{abstract}

Keywords style, influence, job, lecturers, managers, productivity

JEL Classification

I23, M14, J24, J28

\section{INTRODUCTION}

Higher education (hereafter referred to as HE) employees are regularly under stress from the internal environment workloads, research outputs, student matters, and administrative issues, among others. The external environment, such as public funding, autonomy issues, and transformation, to mention a few, compounds this. Interestingly, administrative support staff functions in a similar environment as academic employees (Van Niekerk et al., 2017). Additionally, Van Niekerk et al. (2017) argue that the stress academic and support staff encounter would place further tension on interpersonal relationships. Interestingly, some employees work in silos, incessant office politics, nepotism, and cronyism (friends getting preferential treatment) usually related to managers. In terms of a lack of employee engagement (herein called EE), Marquard (2010) implies that a considerable majority of employees would give less instead of giving more of them. 
Employees are also known as followers or rather organizational followers of a leader at all organization levels. Moreover, from a perspective, academic and administrative employees are imperative for sustainability, economic development, and support of universities. In South Africa (herein called SA), when academics and support staff collaborate, this will significantly impact student education and support possible future opportunities. However, an unfair workload allocation can affect employees, resulting in disengagement. Academics and support staff play a vital part in the economic growth and future of SA (Van Niekerk et al., 2017). Hence, the conglomeration of new research on EE or disengagement is needed to impress employees' importance. Cook (2008) believes EE is all about employees' readiness and skill to give open effort to support organizational success. When employees feel trusted, respected, appreciated, engaged, dedicated, and are personally involved; there are high levels of inspiration and passion. Besides, it is vital for HEIs to care for, protect, and manage employees' well-be HEIs need to care outlook on the intellectual health of SA (Van Niekerk et al., 2017).

Therefore, this paper examines the concept of EE to determine if employees are currently engaged on not and what could be the potential factors that influence employee engagement or disengagement within a HE setting.

\section{LITERATURE REVIEW}

Schaufeli and Bakker (2001, pp. 229-253) defined engagement as a positive, satisfying, work-related viewpoint characterized by enthusiasm, dedication, and attentiveness. Employee engagement can be defined as the connection of employees to their occupation of the organization, as individuals work and physically, cognitively, and meaningfully express themselves (Lewis et al., 2012, p. 34). Employees are the heart, feet, and hands of organizational development (Masemola, 2011). As Iqbal et al. (2015, p. 1) stated, employees are a crucial resource for practically every organization, particularly as employees represent a noteworthy investment in locating, hiring, training, strategies, bonuses, etc. Notably, the initial step is that leaders need to ensure leaders themselves are engaged before being concerned with employees' engagement (De Mello E Souze Wildermuth \& Pauken, 2008, pp. 122-128). The tough economic climate and restructuring and resizing have brought $\mathrm{EE}$ to the forefront to preserve and develop it throughout difficult times (Nolan, 2011, p. 3). Employers have now realized EE will create a more competent and dynamic labor force, and any ingenuities of progress by management will not be successful without participation and employee engagement (Kompaso \& Sridevi, 2010). It is vital to note that employees are the organization's principal asset as they represent the intellectual capital of an organization (Denton \& Vloeberghs, 2003).
Over the years, there has been an outpouring of attention in EE (Dromey, 2014, p. 7). It should be noted that an organization that can unlock the enigma of employee engagement is assured returns beyond its wildest dreams (Swarnalatha \& Prasanna, 2013). According to Kahn (1990), engaged employees are attached to the workplace, while disengaged employees are detached from the organization. Employee engagement is about ensuring a suitable atmosphere to have the ability and potential to do their best every day (Hirtle, 2016). Furthermore, according to Cook (2008, p. 3), engagement is about how employees perform duties positively and proactively. Harter, Schmidt, and Hayes (2002) claim that EE refers to personal participation and fulfillment along with a zest for work.

There are four enablers of engagement that have become highly influential as a method for framing successive work on engagement (Dromey, 2014):

$$
\begin{aligned}
& \text { - } \quad \text { strategic narrative - leadership; } \\
& \text { - engaging managers; } \\
& \text { - integrity. }
\end{aligned}
$$

Employee engagement concerns an individual at an intrinsic level who cannot be instructed or enforced by others. EE is a personal-level concept that needs to be better understood from each individual's perspective, department, and team (Shuck \& Wollard, 2010). It is believed that engaged em- 
ployees are more likely to be dedicated and thus would have resulted in a lower staff turnover in the organization (Schaufeli \& Bakker, 2004).

Disengagement is a process by which individuals progressively discontinue being involved in a conflict, occupation, or organization; additionally, disengagement synonyms are known as disconnection, withdrawal, or detachment (Collinsdictionary.com, 2017). Employee disengagement can be identified by low morale, high absenteeism, high stress levels, inefficient decision-making, office politics, ineffective communication, and bad company values communiqué (Cook, 2008, p. 19). Employees who are engaged are psychologically and physically in better health than those who are disengaged (Hansen et al., 2014). Employees that feel disregarded and less appreciated are less motivated to be engaged within the organization. It includes common goals not achieved, reduced performance, missed commitment, excuses and blames, workload complaints no solution, 'corridor' talks resulting in no change (Hirtle, 2016). If the organizations' culture overlooks employee engagement, there would be a vicious circle of employee disengagement (Lewis et al., 2012). According to Hirtle (2016, p. 5), disengaged employees are inclined to foster a negative workplace philosophy. Harter et al. (2002) claimed that several individuals are going to work day after day and are actively disengaged at work. When employees view a manager's efforts on engagement as a cosmetic exercise with no consequence, it will lead to employee disengagement (Dromey, 2014).

Occupational stress can be defined as the interpretation by an employee or person (mental interpretation) of certain selected environmental variables (stressors) as stress-inducing (Barkhizen \& Rothmann, 2008). Occupational stress is believed to have a spillover effect whereby it becomes a major factor in the overall quality of life, including the nuclear family life (Doyle \& Hind, 1998). According to Gillespie et al. (2001), a study on academia and stress claimed the effect of being psychological, a sense of anxiety, depression, burnout, annoyance, irritability, and powerlessness. Academics working for prolonged hours have now been acknowledged as causing severe risk to health and well-being (Barkhizen \& Rothmann, 2008, p. 321). Employee burnout is defined as a pattern of emotive fatigue, depersonali- zation, and low individual achievement among employees in a workplace (Maslach \& Jackson, 1985) from a positive psychological perspective. Burnout on the job can be redefined as the destruction of EE. It comprises two components and can be defined as a person who feels exhaustion and disengagement from work (Van Niekerk, 2016, p. 9). As Schaufeli and Bakker (2001), Turner, Barling, Epitropaki, Butcher, and Milner (2002) claimed, burnout at work could be chiefly responsible for illnesses and negative well-being. Barkhuizen and Rothmann (2008, p. 333) confirmed that academic stress related to worklife balance results in burnout and physical consequences, such as headache, back pain, stomachache, exhaustion, and lack of sleep. The aforementioned has been well investigated, established, a documented fact that employee burnout is a certainty at HEIs (Tytherleigh et al., 2008). Tytherleigh et al. (2008) claimed that the growing levels of exhaustion and disparagement have been related to research on burnout amongst South African academics. Viljoen and Rothmann (2009) maintain that psychological ill health could be burnout within the South African HEIs background, resulting from arduous relationships, time pressures, poor learner discipline, inappropriate promotion policy, overworking, and lack of resources. A study showed that $29 \%$ of female educators showed increased emotional tiredness levels (Rothmann, 2003). Organizational commitment of academics in HEIs will deteriorate because of stress, autonomy deprivation, lack of proper training, equipment, and resources, and if the vital parts of the occupation are stressful, result in staff turnover (Barkhuizen \& Rothmann, 2008). Masemola (2011, p. 32) asserted that turnover is well defined as workers' movement out of the institution. Morrell, Loan-Clarke, and Wilkinson (2004) claim that employee turnover could further increase organizational costs arising from recruitment, selection, training, or temporary staff employment. As Masemola (2011) asserted, the research has shown job unhappiness as one of the key drivers of employee turnover. Bothma and Roodt (2013) state that studies have revealed that an intention to leave an organization is an indicator of employee turnover. Mitchell et al. (2001) and Schaufeli and Bakker (2004) propose that turnover intention would usually be motivated by the absence of job embeddedness and disengaged employees. Younger employees are more inclined to turnover than older employees (Masemola, 2011, p. 38). Hence, 
when an employee is disengaged, these employees are more prone to leave the organization (Basikin, 2007). Moral disengagement happens by separating moral effects from callous or unethical behavior and restricting the process of self-blame (Fiske, 2004). A leader's moral disengagement specifically might play a significant role in influencing followers. Moreover, as per moral disengagement theory, individuals with set moral values, if breached by others, would lead to personal distress and self-condemnation (Bonner et al., 2014). Moreover, Detert, Trevino, and Sweitzer (2008) asserted that moral disengagement demonstrates the reason normal individuals freely get involved in immoral conduct without any responsibility or self-consciousness for the disengagement.

The connection of equality with leadership is probable based on the principle of collaborative equality (Hansen et al., 2014) and the emphasis on treating employees with respect. Hirtle (201, p. 5) claimed that there is work pressure on managers to attain employee engagement, as the relationship between employee and lower-level managers is the number one reason to stay in or leave a job. Kalshoven and Boon (2012) assert that employees with poor well-being could be less productive, make lower-quality choices and be more absent from work. Furthermore, workers' well-being plays a dynamic function in an organization's success (Macky \& Boxall, 2008). Interestingly, Vance (2006) claims that the former leader Jack Welch of General Electric claimed employee engagement as the first way to evaluate an organization's well-being. Moreover, leaders have the chance to build an impartial work environment by way of making judgments that are perceived as non-discriminatory by employees (Brown et al., 2005, p. 119).

Given the above literature support for the study, the paper takes cognizance of employee engagements and factors thereof and presents the aims of the study in the following section.

\section{AIM}

The study aims to investigate engagement or disengagement across job grade category at a public higher education institution in South Africa and if leadership style impacts this.

\section{METHODS AND HYPOTHESIS}

The primary sources of the data were quantitative questionnaires and semi-structured interviews used to better understand the phenomena. The study utilized a mixed-methods approach that employed quantitative and qualitative methods. The quantitative method was based on simple random sampling, which consisted of a target population of 1,874 , with a sample population of 420 out of a sample size of 312 employees at the institution. Survey questionnaires were randomly administered and obtained a $74 \%$ response rate. The study utilized a 5-point Likert scale for the quantitative questionnaire. The qualitative method, semi-structured interview, used a purposeful sampling technique, with a realized sample size of 12 out of 18 leadership interviews, indicating a response rate of $67 \%$.

\subsection{Analysis of data}

The quantitative analysis involved both descriptive and inferential analysis.

\subsection{Descriptive analysis}

The frequency distribution was done using 13 5-point Likert scale statements, mean value scores, and standard deviation ranging from the highest mean of $\mathrm{M}=3.72(\mathrm{SD}=1.038)$ to the lowest mean of $\mathrm{M}=2.33$ ( $\mathrm{SD}=1.136$ ) for employee engagement (EE) construct.

\subsection{Construct validity of employee engagement questionnaires}

Exploratory Factor Analysis was performed using the extraction method of principal axis factoring with Promax (oblique) rotation method was applied to a set of items (proportion of variance) for employee engagement construct. For the extraction part, 13 items from the employee engagement construct were utilized.

\subsection{Rotation method for employee engagement construct}

Eigenvalues for EE construct were rotated to achieve simple structure by attempting to link 
Table 1. Employee engagement items

Source: Bhana and Suknunan (2019).

\begin{tabular}{|c|c|c|c|c|c|c|c|c|}
\hline \multirow{2}{*}{ Employee engagement } & & \multicolumn{5}{|c|}{ Likert scale } & \multirow[b]{2}{*}{ Mean } & \multirow[b]{2}{*}{ Std. Dev. } \\
\hline & & SD & D & $\mathbf{N}$ & A & SA & & \\
\hline \multirow{2}{*}{ My LML is concerned about staff well-being } & Count & 62 & 85 & 84 & 57 & 24 & \multirow{2}{*}{2.67} & \multirow{2}{*}{1.205} \\
\hline & $\%$ & 19.9 & 27.2 & 26.9 & 18.3 & 7.7 & & \\
\hline \multirow{2}{*}{$\begin{array}{l}\text { I am able to discuss personal staff matters or report a problem } \\
\text { to my LML }\end{array}$} & Count & 73 & 77 & 74 & 63 & 25 & \multirow{2}{*}{2.65} & \multirow{2}{*}{1.259} \\
\hline & $\%$ & 23.4 & 24.7 & 23.7 & 20.2 & 8.0 & & \\
\hline \multirow{2}{*}{ My LML is my confidant and genuinely cares for me } & Count & 84 & 83 & 82 & 47 & 16 & \multirow{2}{*}{2.45} & \multirow{2}{*}{1.183} \\
\hline & $\%$ & 26.9 & 26.6 & 26.3 & 15.1 & 5.1 & & \\
\hline \multirow{2}{*}{$\begin{array}{l}\text { Staff are comfortable to raise issues and ask questions to the } \\
\text { LML }\end{array}$} & Count & 76 & 82 & 57 & 71 & 25 & \multirow{2}{*}{2.64} & \multirow{2}{*}{1.290} \\
\hline & $\%$ & 24.4 & 26.4 & 18.3 & 22.8 & 8.0 & & \\
\hline \multirow{2}{*}{ I am involved in final decision-making } & Count & 89 & 95 & 77 & 38 & 13 & \multirow{2}{*}{2.33} & \multirow{2}{*}{1.136} \\
\hline & $\%$ & 28.5 & 30.4 & 24.7 & 12.2 & 4.2 & & \\
\hline \multirow{2}{*}{ I have a good working relationship with my LML } & Count & 55 & 73 & 78 & 74 & 32 & \multirow{2}{*}{2.86} & \multirow{2}{*}{1.253} \\
\hline & $\%$ & 17.6 & 23.4 & 25.0 & 23.7 & 10.3 & & \\
\hline \multirow{2}{*}{ My LML supports my career development } & Count & 48 & 73 & 97 & 63 & 31 & \multirow{2}{*}{2.86} & \multirow{2}{*}{1.197} \\
\hline & $\%$ & 15.4 & 23.4 & 31.1 & 20.2 & 9.9 & & \\
\hline \multirow{2}{*}{ I carry out tasks beyond my job description } & Count & 33 & 32 & 37 & 98 & 112 & \multirow{2}{*}{3.72} & \multirow{2}{*}{1.329} \\
\hline & $\%$ & 10.6 & 10.3 & 11.9 & 31.4 & 35.9 & & \\
\hline \multirow{2}{*}{ Duties are allocated equitably to all staff } & Count & 69 & 67 & 96 & 55 & 25 & \multirow{2}{*}{2.68} & \multirow{2}{*}{1.224} \\
\hline & $\%$ & 22.1 & 21.5 & 30.8 & 17.6 & 8.0 & & \\
\hline I am motivated and passionate about $m$ & Count & 39 & 42 & 59 & 83 & 89 & 3.45 & 1358 \\
\hline I am motrvated and passionate about my job & $\%$ & 12.5 & 13.5 & 18.9 & 26.6 & 28.5 & 3.45 & 1.358 \\
\hline Lam willing to g & Count & 68 & 66 & 33 & 80 & 65 & 3.03 & 1.476 \\
\hline Tam willing to go & $\%$ & 21.8 & 21.2 & 10.6 & 25.6 & 20.8 & & \\
\hline I am ha & Count & 89 & 77 & 59 & 56 & 31 & 2.56 & 333 \\
\hline 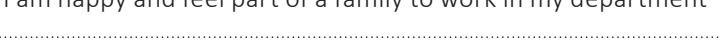 & $\%$ & 28.5 & 24.7 & 18.9 & 17.9 & 9.9 & 2.30 & בנד \\
\hline My IMI insnires and encourages me & Count & 86 & 79 & 66 & 55 & 26 & 254 & 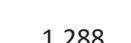 \\
\hline tory Livit inspires a & $\%$ & 27.6 & 25.3 & 21.2 & 17.6 & 8.3 & 2.04 & 1.200 \\
\hline
\end{tabular}

Note: $\mathrm{LML}$ - line management leadership.

the calculated factors to the theory of the study. Table 2 exhibited the pattern matrix or facThus, to obtain correlation amongst these factors, tor-loading matrix results on EE constructs. The Promax rotation with Kaiser normalization does factor loading matrix should be greater than 0.40 oblique rotation with several factors, as seen in to be considered significant and the desired coeffiTable 2 . cient. Moreover, Table 2 revealed that for employ-

Table 2. Pattern matrix for employee engagement constructs

Source: Bhana and Suknunan (2019).

\begin{tabular}{|c|c|c|}
\hline \multirow{2}{*}{ Employee engagement } & \multicolumn{2}{|c|}{ Factor } \\
\hline & 1 & 2 \\
\hline My LML is my confidant and genuinely cares for me & .939 & \\
\hline Staff are comfortable to raise issues and ask questions to the LML & .919 & \\
\hline I am able to discuss personal staff matters or report a problem to my $L M L$ & .897 & \\
\hline I have a good working relationship with my LML & .854 & \\
\hline My LML inspires and encourages me to perform better & .841 & \\
\hline My LML is concerned about staff well-being & .817 & \\
\hline I am happy and feel part of a family to work in my department & .801 & \\
\hline My LML supports my career development & .686 & \\
\hline I am involved in final decision-making & .651 & \\
\hline I am willing to go the extra mile to help staff in my department & .586 & \\
\hline I am motivated and passionate about my job & & .913 \\
\hline I carry out tasks beyond my job description & & .812 \\
\hline Duties are allocated equitably to all staff & & .478 \\
\hline
\end{tabular}


Table 3. ANOVA results for two measures across job grade category

\begin{tabular}{|c|c|c|c|c|c|c|}
\hline \multicolumn{2}{|c|}{ Job grade } & $\mathbf{N}$ & \multicolumn{2}{|l|}{ Mean } & \multicolumn{2}{|c|}{ Std. Deviation } \\
\hline \multirow{6}{*}{ EE_EXT } & Semi-skilled & 81 & \multicolumn{2}{|l|}{2.6535} & \multicolumn{2}{|c|}{1.03601} \\
\hline & Professional & 58 & \multicolumn{2}{|l|}{2.7466} & \multicolumn{2}{|c|}{1.05002} \\
\hline & Lecturers & 148 & \multicolumn{2}{|l|}{2.5257} & \multicolumn{2}{|c|}{1.08359} \\
\hline & Junior manager & 14 & \multicolumn{2}{|l|}{3.2000} & \multicolumn{2}{|c|}{.98528} \\
\hline & Middle manager & 11 & \multicolumn{2}{|l|}{3.2909} & \multicolumn{2}{|c|}{.82396} \\
\hline & Total & 312 & \multicolumn{2}{|l|}{2.6572} & \multicolumn{2}{|c|}{1.06431} \\
\hline \multirow{6}{*}{ EE_INT } & Semi-skilled & 81 & \multicolumn{2}{|l|}{3.3292} & \multicolumn{2}{|c|}{1.09607} \\
\hline & Professional & 58 & \multicolumn{2}{|l|}{3.2184} & \multicolumn{2}{|c|}{.97643} \\
\hline & Lecturers & 148 & \multicolumn{2}{|l|}{3.1532} & \multicolumn{2}{|c|}{1.12646} \\
\hline & Junior manager & 14 & \multicolumn{2}{|l|}{3.8810} & \multicolumn{2}{|c|}{1.07502} \\
\hline & Middle manager & 11 & \multicolumn{2}{|l|}{4.2727} & \multicolumn{2}{|c|}{.74264} \\
\hline & Total & 312 & \multicolumn{2}{|l|}{3.2831} & \multicolumn{2}{|c|}{1.09986} \\
\hline \multicolumn{7}{|c|}{ ANOVA } \\
\hline & & Sum of squares & df & Mean square & $\mathbf{F}$ & Sig. \\
\hline \multirow{3}{*}{ EE_EXT } & Between groups & 11.567 & 4 & 2.892 & 2.605 & ${ }^{*} 0.036$ \\
\hline & Within groups & 340.722 & 307 & 1.110 & & \\
\hline & Total & 352.288 & 311 & & & \\
\hline & Between groups & 18.691 & 4 & 4.673 & 4.012 & $* 0.003$ \\
\hline EE_INT & Within groups & 357.522 & 307 & 1.165 & & \\
\hline & Total & 376.213 & 311 & & & \\
\hline
\end{tabular}

ee engagement, 10 out of 13 items belong to factor 1 , whereas 3 out of 13 items conform to factor 2 .

H1: Employee engagement measures are not significantly different across job grade category.

H1: Employee engagement measures are significantly different across job grade category.

Table 3 depicted the variance analysis comparing the means of job grade group concerning employee engagement (external and internal). There is a significant difference in the EE_EXT measure across grade-level categories, $\mathrm{F}(4,307)=2.605$, $p=0.036$. Moreover, the significant difference in agreement mean score is lower for lecturer grade $(\mathrm{M}=2.5257, \mathrm{SD}=1.08359)$ than middle manager grade $(\mathrm{M}=3.2909, \mathrm{SD}=0.82396)$, indicating more difference in EE_EXT for middle manager grade compared to lecturer grade. It also indicated that lecturer grade is more work engaged than middle manager grade. Respectively, EE_INT demonstrated a significant difference across job grade categories, $\mathrm{F}(4,307)=4.012, p=0.003$. However, for EE_INT, the difference in mean scores for middle manager job grade $(\mathrm{M}=4.2727, \mathrm{SD}=0.74264)$ is higher than the overall job grades. Although the other grades could imply a difference, they have not shown a statistically significant difference in results. Besides, the results indicate that the middle manager grade is not intrinsically engaged compared to the other job grades. Therefore, $\mathrm{Hl}_{1}$ is accepted.

\section{RESULTS}

Thematic and interpretive analysis was used, and the following was found.

\subsection{Leadership style impact on employee engagement}

All participants supported that leadership styles influenced employee engagement, which was further supported by the findings in the following ways, as narrated further.

All line management leadership (herein called LML) viewed employees as the face of the organization. However, one participant made a noteworthy point that "I think employee are the face of the organization, but also think the face of the organization is also a lot about how people are treated by processes and procedures....". Leadership style played a key role; hence, the employee could be either motivated or disruptive based on leadership style. However, LML will always have the 
authority to lead, as per participant 7, "I believe that leadership styles impact department employee." Therefore, LML needs to lead by example, as claimed by participant 8: Employees are work engaged depending on the leadership style, employees are either motivated or disruptive, must lead by example. This further coincided with the leadership view on staff well-being, whereby participant 7 asserted, "Yes, the role is taken seriously, and I understand the importance of leadership, so staff well-being, drive and commitment important."

However, one participant felt that their department was partially engaged as some employees only saw their job for the salary, while some were dedicated and engaged in their work. However, every LML has its modus operandi, which can affect employees; as per participant 5, "the LML is judged by what one is not doing, not what LML does." Moreover, another participant made a strong point that there were variations whereby some employees were stuck in their jobs for many years without progress, thus negatively impacted work engagement. Furthermore, there are times when people are work-engaged but also times when they are not (act as if they are on a scholarship), as supported by participant 2 , "There is need for further emphasis on EE in my faculty."

\subsection{Importance of employee engagement}

The findings revealed that LML viewed employee well-being, drive, and commitment as important in their departments. As conveyed by participant 7, "The role is taken seriously, and I understand the importance of leadership, so employee well-being, drive and commitment is important." Furthermore, maintaining committed employees to enhance productivity. The employee needed to be treated well and be valued so that they would do the same to the stakeholders they serve through their work. Besides, it promoted cooperation and support, created and respected boundaries. Moreover, engagement had a positive effect on work and productivity since it allows the employee to be kept informed of the latest happenings and developments and a platform to keep the employee motivated and promote participation. As per participant 11, "Department EE is very important - if employees don't care deeply about their work, and their job is working with people, then they are at risk of treating people like numbers." It was important to recognize individual employee contribution through EE. Employee engagement also promoted an avenue to resolve issues and conflicts. A positive finding was that most participants agreed that they were impartial to all employees. While two participants mentioned that EE only happened sometimes, one participant conveyed that it was very difficult to obtain EE. As per participant 5, "LML needs time to engage with individuals and groups, very difficult to achieve EE." Qualitative findings further reflected that respondents did view employee well-being, motivation, and loyalty as important as shown by Participant 8: Employees are work engaged depending on the leadership style, employees are either motivated or disruptive, must lead by example. One participant made an important point that "I think employee are the face of the organization, but also think the face of the organization is also a lot about how people are treated by processes and procedures...." This was a noteworthy point.

\section{DISCUSSION}

The findings showed (Table 1) that $67.3 \%$ employees are doing tasks beyond their job description. Thus, indicating that these respondents are doing more work will lead to discontentment and/or burnout over time. Previous research has shown that employees who work beyond job description will result in high employee turnover. Barkhuizen and Rothmann $(2008$, p. 333) stated that commitment of academics in HEIs will deteriorate because of stress, autonomy deprivation, lack of proper training, equipment, and resources. If the vital parts of the occupation are stressful, it results in staff turnover. The descriptive analysis findings showed that $44.2 \%$ of employees would switch jobs should a better job offer arise. These results imply that occupational stress may lead to employee turnover and result in a "brain drain" of employees relative to employee disengagement.

Unusually, there was an opposition of responses regarding employees' willingness to help department staff with $46.4 \%$ in agreement and $43 \%$ disagreement. This is supported by Gallup (2016, p. 2) that without his employees willing to do more 
than their job description, it will have a ripple effect on scholars and other stakeholders as they will be less likely to be engaged in their learning equipped for life. Formidably, this uncertainty of employees not willing to go the extra mile may give rise to employee disengagement and eventually impact stakeholders over time. Leader employee cooperation, engagement, and willingness to put in the extra effort are essential, especially during challenging times. Engagement is a combination of mindset and conduct, mindset is dedication or allegiance, and conduct is the willingness of individuals to go the extra mile (Dromey, 2014). Thus, this area requires further attention at lower leadership levels of the institution.

There is more engagement at lecturer grade as compared to middle manager grade and significant difference in agreement mean score between lecturer grade and middle manager grade. A leader's moral disengagement specifically might play a significant role in influencing followers (Bonner et al., 2014). The results show a difference in EE across job grade categories, with mean values being higher for middle manager job grade higher than the overall job grades, which implies that middle manager grade is not engaged compared to the other job grade levels. Hirtle (2016, p. 5) claimed that there is work pressure on managers to attain $\mathrm{EE}$, as the relationship between employee and lower-level managers is the number one reason to stay in or leave a job. This shows EE measures are significantly different across job grade category.

Moreover, the results have indicated that LML styles impact EE. As Hirtle (2016) claimed, much pressure has been placed on managers to attain EE as the relationship between employee and LML is the number one reason employees stay or leave a job. Employees are the heart, feet, and hands of organizational development (Masemola, 2011, p. 11). This may imply that line manager's leadership style has an impact on personal engagement (EE INT), which is supported by Schulze (2006, p. 320) who affirmed that intrinsic satisfaction regarding the ingenious and challenging nature of the work had greater significance than working conditions (for example, promotion, advancement, workload, and salary). This was consistent with the qualitative findings that participants viewed employee well-being, motivation, and loyalty as important aspects in a department as it impacted team spirit and development.

\section{CONCLUSION}

Analyzing and understanding the drivers of engagement can help identify where and how engagement initiatives should be targeted. The study, therefore, makes an original contribution to this area as it depicted a clear indication of employee disengagement and its implications at a public higher education institution in South Africa. Such disengagement can lead to occupational stress, employee burnout, moral disengagement, and employee turnover at the institution. Employees were overworking, and workloads were not distributed. Besides, they did not feel a sense of belonging or part of the team and did not feel motivated by their line manager. There was more engagement at lecturer grade level than middle manager grade level, and middle manager grade level is not as engaged as it should be given their mandatory role in the institution. The study also found that leadership style does impact employee engagement, and, therefore, leadership style must be cognizant of the concept of employee engagement. As indicated, communication and understanding employees' expectations and the provision of required resources needed to perform their work are very important. A sense of belonging is important, particularly as the organization aims to reduce job turnover and optimize productivity. This can be achieved with leaders playing a role in taking an interest in employees and creating a feeling of self-worth and growth opportunities. The recommendation is that there must be a more open relationship between management and employees with more platforms for engagement. The benefits of an engaged workforce are wide-ranging. They can increase productivity and instill company loyalty and trust, which can trickle down to stakeholders as well. The study findings were limited to employees at just one large South African higher education institution. Besides, the study primarily focused on executive management and line management leadership levels at the institution. Future research could entail a study across multiple public higher 
education institutions in South Africa and be conducted at different management levels at these institutions. Furthermore, studies investigating transformative and positive leadership in South African's higher education are recommended.

\section{AUTHOR CONTRIBUTIONS}

Conceptualization: Anrusha Bhana, Sachin Suknunan.

Formal analysis: Anrusha Bhana.

Investigation: Anrusha Bhana.

Methodology: Anrusha Bhana, Sachin Suknunan.

Project administration: Anrusha Bhana.

Supervision: Sachin Suknunan.

Validation: Anrusha Bhana, Sachin Suknunan.

Visualization: Anrusha Bhana, Sachin Suknunan.

Writing - original draft: Anrusha Bhana.

Writing - review \& editing: Anrusha Bhana, Sachin Suknunan.

\section{REFERENCES}

1. Barkhuizen, E. N., Rothmann, S., \& Tytherleigh, M. Y. (2004). Burnout of academic staff in an HEI. Paper presented at the Second South African Work Wellness Conference. Potchefstroom, South Africa.

2. Barkhuizen, E. N., \& Rothmann, S. (2008). Occupational stress of academic staff in SAHE institutions. South African Journal of Psychology, 38(2), 321336. https://doi.org/10.1177\% 2F008124630803800205

3. Basikin, B. (2007). Vigor, dedication and absorption: Work engagement among secondary school English teachers in Indonesia. Paper presented at the AARE Conference. Fremantle, Perth.

4. Bhana, A., \& Suknunan, S. (2019) The impact of ethical leadership on employee engagement within a South African public higher education institution. Problems and Perspectives in Management, 17(4), 314-324. https://doi. org/10.21511/ppm.17(4).2019.26

5. Bonner, J. M., Greenbaum, R. L., \& Mayer, D. M. (2014). My Boss is Morally Disengaged: The Role of Ethical Leadership in Explaining the Interactive Effect of Supervisor and Employee Moral Disengagement on Employee
Behaviors. Journal of Business Ethics, 137(4), 731-742. Retrieved from https://link.springer.com/article/10.1007/s10551-014-2366-6

6. Bothma, C. F., \& Roodt, G. (2013). The validation of the turnover intention scale. SA Journal of Human Resource Management, 11(1), 1-12. Retrieved from https://core.ac.uk/download/ pdf/26939089.pdf

7. Brown, M. E., Treviño, L. K., \& Harrison, D. A. (2005). Ethical leadership: A social learning perspective for construct development and testing. Organizational Behavior and Human Decision Processes, 97(2), 117-134. https://doi.org/10.1016/j. obhdp.2005.03.002

8. Collinsdictionary.com. (2017). Definition of disengagement. Retrieved from https://www.collinsdictionary.com/dictionary/ english/disengagement (accessed on May 22, 2017).

9. Cook, S. (2008). What is employee engagement? London, GBR: Kogan Page Publishers. Retrieved from https://www.custominsight.com/ employee-engagement-survey/ what-is-employee-engagement.asp

10. De Mello E Souza Wildermuth, C., \& Pauken, P. D. (2008). A perfect match: decoding employee engagement-Part I: Engaging cultures and leaders. Industrial and Commercial Training, 40(3), 122-128. Retrieved from https://www.researchgate.net/ publication/233494053_A_perfect_match_Decoding_employee_engagement_-_Part_I_Engaging_cultures_and_leaders

11. Denton, M., \& Vloeberghs, D. (2003). Leadership challenges for organisations in the new South Africa. Leadership \& Organization Development Journal, 24(2), 84-95. Retrieved from https:// www.researchgate.net/publication/235313012_Leadership_challenges_for_organisations_in_the New_South_Africa

12. Detert, J. R., Trevino, L. K., \& Sweitzer, V. L. (2008). Moral disengagement in ethical decision making: a study of antecedents and outcomes. Journal Applied Psychology, 93(2), 374-391. Retrieved from https://pubmed. ncbi.nlm.nih.gov/18361639/

13. Doyle, C., \& Hind, P. (1998). Occupational stress, burnout and job status in female academics. Gender, Work \& Organization, 5(2), 67-82. https://doi. org/10.1111/1468-0432.00047

14. Dromey, J. (2014). Macleod and Clarke's concept of employee engagement: an analysis based on the Workplace Employment Relations Study. 
15. Fiske, S. T. (2004). Social beings: core motives in social psychology. Hoboken, NJ: J. Wiley. Retrieved from https://www.wiley.com/enus/Social+Beings $\% 3 \mathrm{~A}+$ Core + Moti ves+in+Social+Psychology $\% 2 \mathrm{C}+4$ th+Edition-p-9781119492108

16. Gallup. (2016). State of the Global Workplace Report, 2016. The Engaged University. Retrieved from http://www.gallup.com/services (accessed on 4 April 2017).

17. Gillespie, N. A., Walsh, M., Winefield, A. H., Dua, J., \& Stough, C. (2001). Occupational stress in universities: Staff perceptions of the causes, consequences and moderators of stress. Work \& Stress, 15(1), 53-72. Retrieved from https:// www.tandfonline.com/doi/ abs/10.1080/02678370117944

18. Hansen, A., Byrne, Z., \& Kiersch, C. (2014). How interpersonal leadership relates to employee engagement. Journal of Managerial Psychology, 29(8), 953-972. Retrieved from https://psycnet.apa.org/record/2014-44715-003

19. Harter, J. K., Schmidt, F. L., \& Hayes, T. L. (2002). Businessunit-level relationship between employee satisfaction, employee engagement, and business outcomes: a meta-analysis. Journal of Applied Psychology, 87(2), 268-279. https://psycnet.apa.org/ doi/10.1037/0021-9010.87.2.268

20. Hirtle, C. (2016). Employee engagement for workplace success. Retrieved from www.csmls.org

21. Iqbal, A., Tufail, M., \& Lodhi, R. (2015). Employee loyalty and organizational commitment in Pakistani organizations. Global Journal of Human Resource Management, 3(1), 1-11. Retrieved from https://www.eajournals. org/journals/global-journal-ofhuman-resource-managementgjhrm/vol-3issueljanuary-2015/ employee-loyalty-organizationalcommitment-pakistani-organizations/

22. Kahn, W. A. (1990). Psychological conditions of personal engagement and disengagement at work. Academy of Management
Journal, 33(4), 692-724. Retrieved from https://journals.aom.org/ doi/10.5465/256287

23. Kalshoven, K., \& Boon, C. T. (2012). Ethical Leadership, Employee Well-Being, and Helping. Journal of Personnel Psychology, 11(1), 60-68. https:// psycnet.apa.org/doi/10.1027/18665888/a000056

24. Kinman, G., \& Jones, F. (2003). Running Up the Down Escalator': Stressors and strains in UK academics. Quality in Higher Education, 9(1), 21-38. https://doi. org/10.1080/13538320308162

25. Kompaso, S. M., \& Sridevi, M. S. (2010). Employee engagement: The key to improving performance. International Journal of Business and Management, 5(12), 89. Retrieved from http://www.ccsenet.org/journal/index.php/ijbm/ article/view/6745

26. Lewis, A., Thomas, B., \& Bradley, O. (2012). Employee socialisation: A platform for employee engagement? International Journal of Employment Studies, 20(1), 25. Retrieved from https:// www.semanticscholar.org/paper/ Employee-socialisation\%3A-Aplatform-for-employee-Lewis-Tho mas/3d4d6fccdac400a3458959005 aff72a50824a3f7

27. Macky, K., \& Boxall, P. (2008). High-involvement work processes, work intensification and employee well-being: A study of New Zealand worker experiences. Asia Pacific Journal of Human Resources, 46(1), 38-55. Retrieved from https://www.researchgate.net/ publication/254078235_High-involvement_work_processes_work intensification_and_employee_well-being_A_study_of_New_ Zealand_worker_experiences

28. Marquard, M. J. (2010). Leadership behavior impact on employee engagement. Doctorate of Education Technology and Leadership, Pepperdine University. Retrieved from https://search.proquest.com/ docview/500031547?pqorigsite $=$ gscholar

29. Masemola, S. E. (2011). Employee turnover intentions, organizational commitment and job satisfaction in a post-merger tertiary institution: the case of the University of Limpopo. Master of Business Administration, University of Limpopo (Turfloop Campus).

30. Maslach, C., \& Jackson, S. E. (1985). The role of sex and family variables in burnout. Sex Roles, 12(7-8), 837-851. Retrieved from https://link.springer.com/article/10.1007/BF00287876

31. Maslach, C., \& Leiter, M. P. (1997). The truth about burnout: How organizations cause stress and what to do about it. San Francisco: Jossey-Bass.

32. Mitchell, T. R., Holtom, B. C., Lee, T. W., Sablynski, C. J., \& Erez, M. (2001). Why people stay: Using job embeddedness to predict voluntary turnover. Academy of Management Journal, 44(6), 1102 1121. https://journals.aom.org/ doi/10.5465/3069391

33. Morrell, K. M., Loan-Clarke, J., \& Wilkinson, A. J. (2004). Organizational change and employee turnover. Personnel Review, 33(2), 161-173. https://doi. org/10.1108/00483480410518022

34. Nolan, S. (2011). Employee engagement. Strategic HR Review. https://doi.org/10.1108/ shr.2011.37210caa.001

35. Rothmann, S. (2003). Burnout and engagement: A South African perspective. SA Journal of Industrial Psychology, 29(4), 16-25. Retrieved from https://ovc.ojp. gov/sites/g/files/xyckuh226/files/ media/document/os_burnout_engagement-508.pdf

36. Schaufeli, W., \& Bakker, A. (2001). Work and well-being: towards a positive approach in occupational health psychology. Gedrag \& Organisatie, 14, 229253. Retrieved from https:// www.researchgate.net/publication/287890847_Work_and_wellbeing_Towards_a_positive_occupational_health_psychology

37. Schaufeli, W., \& Bakker, A. (2004). Job demands, job resources, and their relationship with burnout and engagement: A multi-sample study. Journal of Organizational 
Behavior, 25(3), 293-315. https:// doi.org/10.1002/job.248

38. Schulze, S. (2006). Factors influencing the job satisfaction of academics in higher education. South African Journal of Higher Education, 20(2), 318-335. https:// doi.org/10.4314/sajhe.v20i2.25576

39. Shuck, B., \& Wollard, K. (2010). Employee engagement and HRD: A seminal review of the foundations. Human Resource Development Review, 9(1), 89-110. https://doi.org/10.1177\%2F1534484309353560

40. Swarnalatha, C., \& Prasanna, T. (2013). Employee engagement: The concept. International Journal of Management Research and Reviews, 3(12), 3872.

41. Turner, N., Barling, J., Epitropaki, O., Butcher, V., \& Milner, C. (2002). Transformational leadership and moral reasoning.
Journal of Applied Psychology, 87(2), 304-311. https://doi. org/10.1037/0021-9010.87.2.304

42. Tytherleigh, M., Rothmann, S., \& Barkhuizen, N. (2008). Model of work-related ill health of academic staff in a SAHE institution. South African Journal of Higher Education, 22(2), 404422. Retrieved from https://www. ajol.info/index.php/sajhe/article/ view/25794

43. Van Niekerk, W. M. (2016). Assessing conflict management styles and work-related wellbeing of employees in higher education in South Africa. Degree Magister Commercii in Industrial Psychology of the North-West University. Retrieved from https://dspace.nwu.ac.za/handle/10394/21147

44. Van Niekerk, W. M., De Klerk, M., \& Pires-Putter, J. K. (2017). Conflict management styles and work-related well-being among higher education employees. Journal of Psychology in Africa, 27(3), 221-226. Retrieved from https://www.researchgate.net/ publication/332606016_Conflict_ management_styles_and_workrelated_well-being_among_higher_education_employees

45. Vance, R. J. (2006). Employee engagement and commitment: $A$ guide to understanding, measuring and increasing engagement in your organization. Alexandria, VA: SHRM Foundation.

46. Viljoen, J. P., \& Rothmann, S. (2009). Occupational stress, ill health and organizational commitment of employees at a university of technology. $S A$ Journal of Industrial Psychology, 35(1), 67-77. Retrieved from http://www.scielo.org.za/scielo.php?script=sci_arttext\&pid $=$ S2071-07632009000100008 